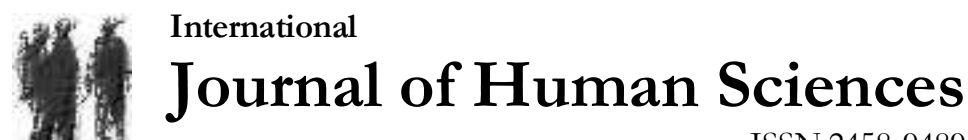 \\ ISSN:2458-9489
}

Volume 15 Issue 2 Year: 2018

\section{The relationship between self-efficacy beliefs of school administrators and effective school leadership}

\author{
Erol Ata ${ }^{1}$ \\ Nezahat Güçlü ${ }^{2}$
}

\begin{abstract}
The aim of this study is to examine the relationship between self-efficacy beliefs of school administrators working in Anatolia High Schools and vocational High Schools and effective school leadership. In line with the aim of the study, self-efficacy, school administrators' self-efficacy, effective school leadership and a conceptual framework were explained in introduction part of the study. The sample of the study is comprised of 60 school administrators and 1050 teachers working in Central Anatolia Region cities Kırşehir, Kayseri, Ankara, Nevşehir, Kırıkkale, Aksaray and Yozgat. The School Administrators Self-Efficacy Scale formed by McCollum, Kajs and Minter (2009) was used in order to obtain data from the school administrators in the study. Furthermore, The Effective School Leadership Scale formed by the researchers with the help of the questionnaires used by Balc1 (2001) and Dağlı (2000) so as to measure the effective school leadership. The validity and reliability studies of the both scales used in the study were carried out by the researcher. According to the findings of the study, there is a significant relationship in the same way between the self-efficacy beliefs of the school administrators and the effective school leadership levels according to the opinions of the teachers. The self-efficacy levels of the school administrators also predict their effective school leadership levels. The self-efficacy beliefs of the school administrators and the effective school leadership levels according to the opinions of the teachers were measured in high levels.
\end{abstract}

Keywords: Effectiveness, effective school, effective school leadership, self-efficacy.

\section{Introduction}

The self-efficacy is defined as doing a certain task in an effective way (Bandura, 1997; Chen, et al., 2004; Gist and Mitchell, 1992). Self-efficacy can give us some clues about the selfactualizations of the individuals, accusing of oneself, depression levels, experiences and achievements (Bandura, 1998; Wood and Bandura, 1989). Those having high level of self-efficacy perception are able to show efforts for long durations in discovering and intellectual tasks. It is necessary to have a high level of self-efficacy in technological achievements in particular (Bandura, 1999; Gits and Mitchell, 1992; Wood and Bandura, 1989). Briefly, self-efficacy is a crucial focal point in terms of giving an idea about the tasks which can be performed by individuals in the future (Markman, Baron and Balkin, 2005).

\footnotetext{
${ }^{1}$ Dr., Lecturer, Amasya University, Education Faculty, Depertmant of Educational Sciences, erolata.ea@gmail.com

2 Prof. Dr., Gazi University, Gazi Education Faculty, Depertmant of Educational Sciences, nguclum@gmail.com 
Ata, E., \& Güçlü, N. (2018). The relationship between selfself-efficacy beliefs of school administrators and effective school leadership. Journal of Human Sciences, 15(2), 1137-1154. doi:10.14687/jhs.v15i2.5197

There are four effective methods for developing the self-efficacy beliefs of the individuals (Bandura, 2002, p. 3-4; Wood and Bandura, 1989): The first one of these is previous successful experiences and speciality in some tasks. This method is the most effective one for increasing the self-efficacy perceptions of the individuals. Past achievements and experiences make strong selfefficacy beliefs of individuals whereas their failures make them feel bad. Those with strong selfefficacy beliefs don't give up in the face of failures. They continue function patiently and trying again and again. The school administrators increase their self-efficacies of the staff by means of careful employment, giving challenging tasks, professional development and teaching, defining targets, supportive leadership and prizes (Lunenburg and Orstein, 2013, p. 90). The second one is taking model as well as observed experiences. The individuals develop their self-efficacies by observing their environment and making comparisons when necessary. They may perceive others' successes as if they had the same achievements, or vice versa. This will also affect their efforts to be shown. The third one is social persuading. Another way of increasing people's self-efficacy beliefs is to encourage them in terms of social aspects. The realistic and logical approaches which are convenient for the individuals' capacities affect their efforts needed to achieve a task and their selfefficacy in a positive way. The social persuading doesn't have any positive effect in situations that are not realistic and logical. (Bandura, 2003, p. 127). The fourth one is psyhological and emotional situations. Judgements of individuals about their talents direct their efforts needed to launch a new task whereas stress and pressure affects their efforts adversely (Woord and Bandura, 1989).

Self-efficacy belief affect individuals in terms of four basic aspects (Bandura, 2002, p, 5-10; Şahin, 2009): Self-efficacy belief affects the cognitive processes in many ways. Purposeful human acts are shaped by the aims which have been thought beforehand and have been made clear. Selfefficacy affects the evaluation of the individuals' talents. The more the individuals have higher levels of self-efficacy beliefs, the more they aim to achieve difficult tasks and focus on completing them. The self-efficacy beliefs of individuals have a significant place in self-regulations of the motivational processes. Motivationals processes are generated cognitively and the individuals direct their behaviours and motivate themselves thanks to predicting the future or their foresight skills. Emotional processes have an effect on the beliefs of individuals as to their coping skills, how much stress they will experience and their motivation levels. Individuals who believe that they will be able to deal with the challenges they confront protect themselves from negative thoughts. On the other hand, those who don't have this kind of self-belief begin to experience stress and complain about lacking skills needed to cope. Individuals are part of the environment in which they live. Therefore, the self-efficacy beliefs of individuals affect their activity preferences and the flow of life process. Individuals tend to believe that they must abstain from the tasks and situations which are beyond their skills (Bandura, 2002; Şahin, 2009).

The first studies on education found a relationship between the teachers' self-efficacies and students' achievements in a positive direction (Armor et al., 1976; Berman et al., 1977). Some studies found a relationship between the school administrators' self-efficacies and their leadership behaviours of the school administrators and teachers' self-efficacies and their teaching acts in a positive direction, as well (Bulanch, Boothe and Pickett, 2006; Hartnett, 1995; Krug et al.., 1990). Recent studies have found that there is a positive relationship between the leadership behaviours of school administrators and student achievement (Bulanch, Boothe and Pickett, 2006; Waters, Marzano and McNulty, 2003). Lots of teachers have stated that the school administrators who have high levels of positive self-efficacy perception affect the student achievement and support the school climate in a positive way as well as inspire others about school mission (Domsch, 2009). According to Bandura (2003), powerful school administrators combine their skills with the ones of teaching staff. They make the staff consider themselves as talented and direct them to the aims of the school and achievement. Thus, a positive environment in which everybody work in collaboration for the school improvement is formed. Numerous studies have shown that leaders always need a high level of self-efficacy belief (Bandura 1977; Bandura and Wood, 1989; Dimmock and Hattie, 1996; Imants and DeBrabander, 1996; Leithwood and Jantzi, 2008; McCormick, 2001; 
Ata, E., \& Güçlü, N. (2018). The relationship between selfself-efficacy beliefs of school administrators and effective school leadership. Journal of Human Sciences, 15(2), 1137-1154. doi:10.14687/jhs.v15i2.5197

Osterman and Sullivan, 1996). Normally, those with high levels of self-efficacy beliefs are better motivated for any task and can show greater efforts. From this point of view, the leaders with high levels of high levels of self-efficacy have a key skill and they are effective leaders or vice versa. Those with low levels of self-efficacy show weak efforts and they are less effective (Abusham, 2010). According to McCollum, Kajs and Minter (2006), the studies carried out on developing the school administrators' self-efficacies and evaluating them focus on positive teacher behaviours, students' outcomes and teacher self-efficacy beliefs extensively despite the limited numbers. Effective school administrators are like the bricks of a good school as generally assumed. School administrators are a secret lock in the school. They manage the schools, form the climate, start the change, provide resources, get together the stakeholders and enable the staff to take responsibility. These tasks are definitely complex and challenging. Which beliefs and feelings are needed for why and how to behave needs professional knowledge and experience. The judgements of school administrators as to their self-efficacies or skills guide them about how to achieve the expected results in the school organization. The perceptions of the school administrators about their skills are needed for regulating the group processes in order to succeed in cognitive performances and obtain the aims (Moran and Gareis, 2005).

School administrators directly affect not only the teachers' self-efficacies and their collective skills as a leader but they also shape the teachers self-efficacies and their collective skills. They also affect school improvement application and this increases expectations from the school administrators (Kurt, 2012; Harris, 2002; Hoy and Miskel, 2010, p, 375). At this point, the competencies of the school administrators, their capacities of improving the current situations, their capabilities as to the expected tasks necessitate to deal with school administration as a professional occupation and to educate the administrators in scientific foundations (Hoy and Miskel, 2010, p, 375; Güçlü, 1997).

The special, effective and privileged positions of the schools always feature the school administration as a profession (Açıkalın, 1998, p, 2). The self-efficacy is very important for developing the characteristics of the educational leaders. Educational leaders with higher selfefficacy beliefs become successful in their schools. Those who lack the self-efficacy perception cannot achieve the school organization's aims (McCollum and Kajs, 2009). The school administrators with high levels of self-efficacy perceptions have crucial roles in improving the schools and make the education effective.

Compared to other educational levels in terms of education quality, the Anatolia high schools are qualified educational organizations which provides effective education and enroll successful students according to exam scores of high school entrance examinations even if their number have increased incredibly. Within this context, it is very important that those schools' administrations must be effective and have high performance, as well. The reasons why the innovations efforts fail in the education systems are primarily attributed to the school administrators, and therefore it can be said that the characteristics of the school administrations determines the quality of the education system and appear as successes or failures in the system (Uluğ, 2010, p. 281).

Which characteristics of a school principal do affect the school and student achievement? This question always attracts the scientists. As it can be seen in the literature, particularly in the international one, school leaders' competencies, self-efficacies and characteristics and the variables affected by them are the main research themes.

The determination and development of principals' qualifications have an important place in increasing the effectiveness of the school organizations and their success. Effective leaders and successful schools immediately attract attention immediately and have a positive image in minds. It is not possible for a school administrator to be successful and effective only with burocratic style of management. As a result, it is expected that defining the characteristics of effective school leaders according to the teachers and evaluation of the effectiveness of the school leaders in terms of some variables such as working experience, school type and employment methods give some conclusive results for the literature. With this study, it is aimed to examine the relationship between the self- 
Ata, E., \& Güçlü, N. (2018). The relationship between selfself-efficacy beliefs of school administrators and effective school leadership. Journal of Human Sciences, 15(2), 1137-1154. doi:10.14687/jhs.v15i2.5197

efficacy beliefs of the school administrators working in Anatolia High Schools and vocational high schools and effective school leadership.

McCullers and Bozeman (2010) applied the School Management self-efficacy measure on 300 school principals in Florida. The purpose of the practice was aimed to test the relationship between self-efficacy and believing in realizing the goals of schools. As a result, a positive relationship was found between believing in realizing school goals and school principal selfefficacy. The target population of the research of Iş1k (2001), which examines the self-efficacy belief in terms of managerial roles, has been formed by the first, middle and senior managers. The general self-efficacy beliefs tested the ability of managers to fulfill the roles they were supposed to fulfill, that is, the level of belief in role adequacy, and found a significant relationship between the two belief levels.

Harris, Day, and Hadfield (2003) conducted a multi-method study to evaluate effective school leadership with a teacher's point of view. There were 36 school principals, 92 teachers, 24 students and parents, 24 senior managers and 24 students. According to the study, school structuring, policies and program implementations give school principals the opportunity to show themselves. Most school principals have delegated their duties in the field of administration. They want to spend more time developing the teachings and innovations. The results from the teacher's perspective were clustered in four areas: Leadership and management, professional friendship, values and vision and continuing professional development. Tahir, Said and Rahman (2011) tried to determine the characteristics of effective school principals in Malaysia, characteristics of effective school mentalities and the study was conducted by interviews and questionnaires with 35 school principals and 1705 teachers according to teacher and manager perceptions were determined in four main dimensions: management skills, learning and teaching, personal characteristics. Cemaloğlu (2007) found that leader-style leadership has the most effect in the research of school managers' leadership styles in terms of different variables; on the other hand, laizzes-faire leader has found no contribution to the effectiveness of the school. Krüger, Witzier and Sleegers (2007) attempted to develop a model to investigate the relationship between the school principal, organizational structure of the school and student outcomes. In the study, the effectiveness of the school principals was assessed by taking into consideration variables such as gender, school size, schoolmate age, the ratio of female teachers, the proportion of young teachers, and the school district (urbanization level).

Such issues as how to develop schools, how to increase the effectiveness and achievements of schools, teacher education, technological developments, improving curriculum, appointment of school administrators have been under discussion all over the world for the last 20 years and in Turkey during the past 10 years. The aim of these attempts is to make schools effective. Effective school term brings "effective school principals" to the mind and in some studies (Nye, 2008), a successful principal means the passport of the success.

Principals are considered as an important reason for the failure of innovation efforts in the education system. In this sense, the qualifications of the principals determines the quality of the whole system in a sense; as the reason for its success or failure in the system (Uluğ, 2010, p. 281). What aspects of a school principal can affect school and student success? This question has always been of interest to researchers. As it has been shown in the literature review, the qualifications, selfefficacy and characteristics of school leaders, and the variables that they affect them, are mostly discussed in foreign countries. The knowledge and development of the school principals' characteristics is an important part of enhancing the effectiveness and success of school organizations. Effective leaders and successful schools attract immediate attention and have a positive image in their surroundings. It does not seem possible for a manager to succeed only with bureaucratic managerial skills. Highly qualified principals are more likely to succeed. The identification of principal self-efficacy is also of great importance in training new ones. Self-efficacy beliefs improved principals can adapt more quickly to management tasks and cause less time loss. 
Ata, E., \& Güçlü, N. (2018). The relationship between selfself-efficacy beliefs of school administrators and effective school leadership. Journal of Human Sciences, 15(2), 1137-1154. doi:10.14687/jhs.v15i2.5197

The identification of these characteristics is also important in terms of shedding light on the training of principal training to be carried out.

The evaluation of school principals has been made generally in research on effective school leadership. Every school principal is not directly involved in the school's teachers. It was also evaluated by taking into consideration the types of appointment of the school principals evaluated by their seniority. However, in this study, the teachers of each school evaluated the effective school leadership characteristics of their school heads. Each school principal was able to assess them because their seniority and assignment types were predetermined. This is important because it is from the first researches made in this direction.

This study may contribute to the research that evaluates the self-efficacy and effective school leadership of the school principal in terms of the topics covered and the method used. It is considered that the school manager developed in the research can contribute to the selection and training of administrators since the self-efficacy scale is a scale that can be applied to the principals who are the school principals and can be applied to candidate administrators. In our country of self-sufficiency, studies have been conducted especially on some field teachers and students, and various self-efficacy scales have been developed, but no studies and measurement tools have been developed to measure the self-efficacy beliefs of school principals. Developed ones have also been applied to limited groups and have not been updated. This work is important in terms of contributing to the work in this area.

In line with this general aim, the following sub-problems have been tried to be answered:

1. What are the self-efficacy levels of the school administrators?

2. What is the school administrators' level of effectiveness according to the opinions of the teachers?

3. Is there a significant relationship between the self-efficacy beliefs of the school administrators and effective school leadership?

4. Do the self-efficacy beliefs of the school administrators predict the effective school leadership significantly?

5. Do the self-efficacy beliefs of the school administrators show any difference according to their employment method?

\section{Method}

\section{Research Model}

This study is a descriptive one which is designed as a survey method. In this study, "The School Administrator Self-Efficacy Scale" was adapted into Turkish Language by the researcher in order to define the relationship between the self-efficacy beliefs of the school administrators and effective school leadership. In addition, "The Effective School Leadership Scale" was formed by the researcher. The former was carried out on the school administrators, while the latter was conducted on the teachers working in the same schools.

\section{Participants}

The population of the study is comprised of public Anatolia High Schools and vocational high schools (commonly known as industy vocational high schools, girl vocational high schools, health vocational high schools tourism hotel and trade vocational high hchools) found in seven cities (Kırşehir, Kayseri, Ankara, Nevşehir, Kırlkkale, Aksaray, Yozgat) in the Central Anatolia Region. The sample of the study consists of 30 Anatolia High Schools and 30 vocational high schools selected randomly in these cities. "The School Administrator Self-Efficacy Scale" was conducted on 60 school administrators working in these schools. "The Effective School Leadership Scale" was carried out on 1050 teachers (16-26 teachers in each school) in the sample. From the purposeful sampling methods, maximum diversity sampling method was preferred in order to define the participants in this study. The main aim of this method is to form a convenient sample 
Ata, E., \& Güçlü, N. (2018). The relationship between selfself-efficacy beliefs of school administrators and effective school leadership. Journal of Human Sciences, 15(2), 1137-1154. doi:10.14687/ihs.v15i2.5197

for the study in a relative manner and to reflect the participants' diversity who are suitable for the research problem of the study (Yıldırım and Şimşek, 2013, p, 135).

As it can be seen in Snijder and Bosker's (2010) multi-level analyze example, the true information was tried to be generated from micro level to macro level (from teachers to school, from students to classroom, from departments to firms). According to the research model, "The School Administrator Self-Efficacy Scale" was conducted on 30 school administrators from 30 Anatolia High Schools and 30 vocational high schools working in selected 7 cities in the Central Anatolia Region and "The Effective School Leadership Scale" was carried out on 1050 teachers and were asked to evaluate their school administrators. In this way, it was aimed to obtain data from small samples and to generalize the obtained data for the bigger groups.

The number of school administrators and teachers who work in the Anatolia High Schools and the vocational high schools found in 7 cities in Central Anatolia Region has been obtained from the Province National Education Directorates and listed in Table 3:

Table 1. The Population and Sample information of the Study

\begin{tabular}{cccc}
\hline School Type & School Number & $\begin{array}{c}\text { Teacher } \\
\text { Number }\end{array}$ & $\begin{array}{c}\text { Defined Sample } \\
\text { Number }\end{array}$ \\
\hline Anatolia High School & 190 & 7.170 & 510 \\
Vocational High School & 304 & 13.562 & 540 \\
Total & 494 & 20.732 & 1.050
\end{tabular}

In this study, the numbers (population $=20.000$ people, sample $=377$, population $=30.000$, sample $=379$ people) stated by Büyüköztürk, Çakmak, Akgün, Karadeniz and Demirel (2011, p. 9698) and sample calculation formulas were used in related to adequate teacher sampling

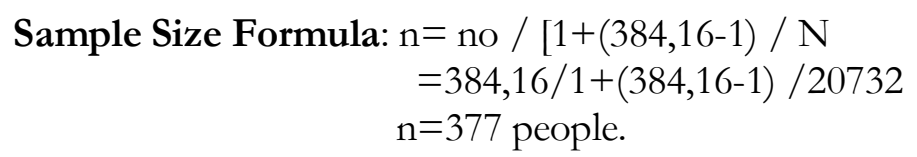

According to this result of the formula, at least 377 people are enough for the sample of the study. In this study, 1050 people were included, which is three times larger than the formula above for the purpose of increasing the reliability.

\section{Data Collection Tools}

As the data collection tool for the study, "The School Administrator Self-Efficacy Scale" was adapted into Turkish Language and "The Effective School Leadership Scale" was formed by the researcher. The validity and reliability tests' results of these scales have been listed below.

\section{The School Administrator Self-Efficacy Scale}

The School Administrator Self-Efficacy Scale is the one with 48 questions which was formed by McCollum, Kajs ve Minter (2009), conducting the validity and reliability tests and referring to the standarts defined by America Education Leaders Selecting Concuil. The permission related to the scales for their usage in scientific studies was asked by means of e-mails. The scale was translated in Turkish Language by a committee including 3 translators. The back translation was also conducted so as to test its compatibility to Turkish Language. Having completed the translation process, the scale was made to check by the field experts in terms of the convenience for the aim of the study and intelligibility. Before the conducting the scale, the potential subjects were asked about the intelligibility of the scale and the necessary corrections were made and it was prepared for the pilot study. 
Ata, E., \& Güçlü, N. (2018). The relationship between selfself-efficacy beliefs of school administrators and effective school leadership. Journal of Human Sciences, 15(2), 1137-1154. doi:10.14687/jhs.v15i2.5197

There must be a certain level of sampling for the purpose of the effectiveness of factor anaylsis to be active and effective. It is generally stated by the researchers that the subjects for the factor analysis test must be at least five times of the variable numbers in the study as a prevalent principle (Alpar 2010, p. 387; Altunışık, Coşkun, Bayraktaroğlu and Yıldırım, 2007, p. 228; Tavşancil, 2006, p. 147). According to this, "The School Administrator Self-Efficacy Scale" was conducted on 150 school administrators from different school levels (primary, secondary and high schools) in this study. The scale has 48 questions and it is a Likert type with 7 items. The adapted scale has also 7 items which is similar to the original one.

The answers which can be given as answers to the scale questions shows an increase towards 7 , whereas they show a decrease towards 1 . The answers to questions range from "totally disagree" to "totally agree", which are scored from 1 to 7 , respectively. Due to the fact that the data collection tool is a likert type scale with 7 items, the obtained results have been considered as; the ones ranging between 1,00-1,84 as "very low", between 1,85-2,70 as "little low", between 2,71-3,56 as "low", between 3,57-4,42 as "moderate", between 4,43-5,29 as "high", between 5,30-6,15 as "little high", between 6,16-7,00 as "very high".

Kaiser-Meyer Olkin (KMO) test for the convenience of the sample size and Barlett's test for sphericity for factor analysis were conducted. The result of the KMO as .60 high level and a meaningful chi-square result have been regarded as the indicator of the compatibility of the data matrix (Büyüköztürk, 2009, p. 126). Based on these results, the scale's validity analysis was done.

Factor loadings between the scores of .30 and .40 are considered as acceptable, .50 and above as significant and .70 and above are considered as the best explanatory factor loadings as to the acceptability of the items in the scale (Alpar, 2010, p. 312) and this scale's factor loading was calculated as .40 and above. Since the compounds explaining the $80-85 \%$ of the eigen value of the total variance in the factor analysis are sufficient (Alpar, 2010, p. 338), the compound explaining at least $80 \%$ of the total variance have been referred. Since the biggest coefficients included in compounds for each question are accumulated under the first compound, this result can be considered as the evidence which means that related questions may accumulate under one dimension. The scale has eight dimensions Each dimension is accumulated under one compound. The rate of the scale's explanation of the total variance is 80.54. Cronbach Alpha reliability coefficient of the scale is .988 .

\section{The Effective School Leadership Scale}

For the development of "The Effective School Leadership Scale", the scale items were formed upon reviewing the international and international literature according to the school administration part of Balc1's (2001, p. 223) the effective school scale and effective school leadership scale formed by Dağl1 (2000), searching for the national and international literature. At the end of this process, a scale of 39 items scale was developed, by consulting field experts. The usage permissions of the scales which were used in this session were requested via e-mails from the owners. The compatibility and intelligibility analyses of the scale were tested by means of preinterviews with school administrators and teachers and the necessary corrections and arrangements were done before the pilot study of the Effective School Leadership Scale with 39 items. In order for factor analysis, a pilot study was carried out on a teacher group including 201 cases from different levels of schools. The validity and reliability tests of the obtained data after the pilot study were performed by using convenient statistical tests. Cronbach Alpha reliability coefficient of the scale was calculated. This scale was formed as a Likert type with 7 items as was in the other scale. For the evaluation of the answers given by the participants, a similar method was followed.

According to Büyüköztürk (2009, p.126), factor analysis may not be suitable for all the data set. The compatibility of the data for the factor analysis can be checked through Kaiser Meyer Olkin (KMO) coefficient and Barlett's test for sphericity. KMO Coefficient gives information whether the data set is convenient for the factor analysis and if the data structure is suitable for removing factors. 
KMO coefficient needs to be higher than .60 for the factor convenience. The fact that chisquare score measured after Barlett test is significant shows the convenience of the data set. According to this information, Kaiser-Meyer Olkin (KMO) test for the convenience of the sample size and Barlett's test for sphericity for factor analysis were conducted and the validity analysis was applied. According to Kaiser-Meyer Olkin (KMO) test and Barlett results, Kaiser-Meyer coefficients (KMO) and Barlett test for sphericity results yielded suitable results (Table 7). KMO must be higher than $0.060(\mathrm{KMO}>0,060)$, chi-square statistics $\left(\mathrm{x}^{2}\right)$ must be meaningful $\mathrm{P}<0,05$. (For this study $\mathrm{KMO}=0.978$, Barlett test $=x^{2}(7411, n=60)=10375,532, P=0,00$ ).

Since the compounds explaining the $80-85 \%$ of the eigen value of the total variance in the factor analysis are sufficient (Alpar, 2010, p. 338), the compound explaining at least $80 \%$ of the total variance have been referred. Seeing that biggest coefficients included in compounds for each question are accumulated under the first compound, and this result can be considered as the evidence which means that related questions may accumulate under one dimension.

Factor loadings between .30 and .40 can be accepted as a criterion related to the acceptability of the items in the scale. .50 and above factor loadings are regarded as significant and .70 and above factor loadings are thought as the best explanatory factor loadings as to the acceptability of the items in the scale (Alpar, 2010, p. 312) and this scale's factor loading was calculated as .40 and above. The scale has six dimensions and each of them is accumulated under one compound. The score of the scale's explaining the total variance is 81.68 . Cronbach Alpha reliability coefficient is .991.

\section{Data Analysis}

The sample of the study was selected from public Anatolia High Schools and vocational high schools in seven cities ((Kırşehir, Kayseri, Ankara, Nevşehir, Kırıkkale, Aksaray, Yozgat) in the Central Anatolia Region. The sample of the study consists of 30 Anatolia High Schools and 30 vocational high schools selected randomly in these cities. "The School Administrator Self-Efficacy Scale" was conducted on 60 school administrators working in these schools. "The Effective School Leadership Scale" was carried out on 1050 teachers (16-26 teachers in each school) in the sample. The necessary permissions were taken from Ministry of National Education.

In this study, Cronbach Alpha reliability coefficients were used for the validity, the factor analyses and the reliability of the scales. The obtained data was analyzed by means of SPSS 20.00 programme. In this context, Spearman Brown rank differences correlation coefficient, simple linear regression analyse Shapiro-Wilk, Independent t-test, One-Way ANOVA, Mann-Whitney U, Kruskal Wallis-H, Kaiser-Meyer Olkin (KMO) and Barlett test were used.

\section{Findings and Discussion}

\section{Self-efficacy Belief Levels of the School Administrators}

The distribution of the statistical data obtained as a result of the self-efficacy scale applied on school administrators working on Anatolia High Schools and vocational high schools is shown in Table 2. 
Ata, E., \& Güçlü, N. (2018). The relationship between selfself-efficacy beliefs of school administrators and effective school leadership. Journal of Human Sciences, 15(2), 1137-1154. doi:10.14687/jhs.v15i2.5197

Table 2. The Self-efficacy Levels of the School Administrators and the Score Distributions of According to the Sub-Dimensions

\begin{tabular}{lcccc}
\hline Sub-Dimensions & $\mathbf{N}$ & $\bar{x}$ & Median & SD \\
\hline Educational Leadership and Staff Development & 60 & 6,16 & 6,3 & 0,63 \\
Development of School Climate & 60 & 6,28 & 6,4 & 0,58 \\
Cooperation with Society & 60 & 6,17 & 6,3 & 0,60 \\
Decision-Making Based on Information in line with & 60 & 6,28 & 6,4 & 0,59 \\
Legal and Ethic Principles & 60 & 6,15 & 6,3 & 0,77 \\
Management of Resources and Services & 60 & 6,11 & 6,3 & 0,84 \\
Utilization of the Resources of the Society & 60 & 6,34 & 6,3 & 0,56 \\
Communication in different Environments & 60 & 6,25 & 6,5 & 0,68 \\
Development of School Vision & 60 & 6,21 & 6,3 & 0,57 \\
\hline Total Mean & & & & \\
\hline
\end{tabular}

As shown in Table 2, the mean of the self-efficacy scores of the school administrators was found as $(\bar{x}=6,21)$. This score shows that the school administrators perceive their self-efficacy beliefs as very high levels. When analyzed according to the sub-dimensions, the highest mean scores are "communications in different environments" with $(\bar{x}=6,34)$ and "development of school climate" with $(\bar{x}=6,28)$. It was found that the sub-dimensions such as decision-making based on information in line with legal and ethic principles and development of school climate with $(\bar{x}=6,28)$ were in high levels in terms of self-efficacy beliefs level. The rest of the other subdimensions also show higher levels of self-efficacy beliefs.

If we consider the self-efficacy studies as the ones in which the individuals evaluate themselves, it can be argued that the individuals generally have positive perceptions in the studies in which the individuals evaluate themselves when compared with the studies in which others evaluate them is one of the reasons of the high scores of the self-efficacy beliefs of the school administrators (Gümüşeli, 1996; İnandı and Özkan, 2006; Karaman 2008).

Similar findings have been obtained in other studies when the gathered data is compared. In one of these studies done by Lovell (2009) with 378 school administrators from primary, secondary and high schools, the means of the scores of self-efficacy beliefs of the schools administrators were found as in high levels. In Nikola's (2013) study which was carried out in South Dakota on the relationship between school administrators and teachers' self-efficacies, it was found that the selfefficacy levels of both groups were at high levels. Ay1k, Savaş and Yücel (2015) found in their study that the general self-efficacy levels of the school administrators were high. McCullers (2009) also carried out a study so as to measure the self-efficacy levels of the school administrators in Florida and found that the mean of the general leadership self-efficacy levels of the school administrators was 4.01 (in Likert type scale with 5 items). In his study, Herriot (2012) found that the mean of the self-efficacy levels of the school administrators in public schools was 4.36 (in Likert type scale with 5 items).

In another study on school administrator's self-efficacy levels done by Moran and Gareis (2005), a self-efficacy scale with 18 items were conducted on 558 school administrators working in primary, secondary and high schools in public schools in Virginia and it was found that the mean scores of the self-efficacy levels of the school administrators was 6.99 and this mean was considered as sufficient for a high level of self-efficacy belief. Aurty (2010) found the mean of the self-efficacy beliefs of the school administrators from 83 schools in Colombia, Maryland and Virginia was 6.02, using the Self Efficacy Scale formed by Moran and Gareis (2005). The mean of the sub-dimension of the self-efficacy instructional leadership and the self-efficacy in administration was found as 5.40. using the Self Efficacy Scale developed by Moran and Gareis (2005), Federici and Skaalvik (2012) performed in a study on self-efficacy levels of the school administrators working in Norway with a sample with 300 school administrators selected randomly and obtained 
Ata, E., \& Güçlü, N. (2018). The relationship between selfself-efficacy beliefs of school administrators and effective school leadership. Journal of Human Sciences, 15(2), 1137-1154. doi:10.14687/jhs.v15i2.5197

the results which shows that the mean of the self-efficacy scores of the school administrations was 5.29 (in Likert type scale with 7 items).

Moak (2010) found a high level of self-efficacy mean scores $(\bar{x}=7,2)$ in his study which was carried out with 123 primary school administrators in Missouri region which aimed at detecting the relationship between the school administrators' self-efficacy levels and student achievement. In the study, the sub-dimensions means were listed as: administration leadership $=6.5$, instructional leadership $=7.5$ and ethical leadership $=7.7$.

O'Neil (2013) who searched the self-efficacy levels the school administrators working in low socio-economic levels found that the mean of the self-efficacy levels of the school administrators was 7.23 , which indicates a high level. The sub-dimensions' means were found as in high levels such as the self-efficacy in instructional leadership $=7.27$ and the self-efficacy in ethical leadership $=7.44$. The self-efficacy in administration was found as 6.84 in moderate level. Simith, Guarino, Storm and Adams (2006) studied on the self-efficacy levels of the school administrators from different levels of schools and focused on two sub-dimensions: administration and instructional applications. It was found that the mean of the administration applications was 2.14 and the mean of instructional applications was 1.83 (in Likert type scale with 4 items).

The mentioned results of the studies above match up with the results of this study, but using different Likert type scale poses some limitations for the study so as to make comparisons in a complete manner because of the different scale variable values (in Likert type scale with 4, 5, 7 or 9 items) and different variables for measuring the self-efficacy levels of the school administrators. Despite these limitations, it can be argued that the results of the studies correspond with this study and the self-efficacy levels of the school administrators are in high levels (Herriot 2012; Lovell 2009; Moak 2010; Moran and Gareis 2005; Nikolas, 2013; O’Neil, 2013; Autry, 2010).

\section{The Effective School Leadership Levels of the School Administrators According to Opinions of the Teachers}

The statistical analyses are listed in table 3 as a result of "The Effective School Leadership Scale" applied to teachers in order for measuring the levels of effective school leadership of the school administrators

Tablo 3. The Effective School Leadership Levels of the School Administrators According to Opinions of the Teachers and the Score Distributions of According to the Sub-Dimensions

\begin{tabular}{lcccc}
\hline Sub-Dimensions & $\mathbf{N}$ & $\bar{x}$ & Median & SD \\
\hline Visionary Leadership & 60 & 4,99 & 5,1 & 0,76 \\
Personal Qualities & 60 & 5,16 & 5,3 & 0,76 \\
Educational Leadership & 60 & 4,90 & 5,0 & 0,79 \\
Understanding and Developing Learning and Teaching & 60 & 5,00 & 5,1 & 0,74 \\
Processes & 60 & 5,08 & 5,2 & 0,76 \\
Compounding the Resources, Planning and Evaluating & 60 & 5,03 & 5,1 & 0,75 \\
Collaboration, Communication and Paying Attention to & 60 & 5,03 & 5,1 & 0,75 \\
Team Work & 60 & & & \\
\hline Total Mean & & &
\end{tabular}

As shown in Table 3, the effective school leadership of the school administrators working in Anatolia High Schools and vocational high schools according to the opinions of the school teachers was found as 5.03 in general. According to this, the effective school leadership levels of the administrators were found as high level. 
Ata, E., \& Güçlü, N. (2018). The relationship between selfself-efficacy beliefs of school administrators and effective school leadership. Journal of Human Sciences, 15(2), 1137-1154. doi:10.14687/jhs.v15i2.5197

When the effective school leadership levels of the school administrators are evaluated in terms of the sub-dimensions, the highest mean scores in the sub-dimensions are personal qualities with $\bar{x}=5,16$ and compounding the resources, planning and evaluating with $\bar{x}=5,08$. Educational leadership with $\bar{x}=4,90$ and visionary leadership with $\bar{x}=4,99$ are the ones which show the lower mean scores than the other sub-dimensions. According to these findings, the teachers perceived the school administrators' effective school leadership levels as high.

Güçlü and Tunçel (2010) studied on the effectiveness of the normal high schools and Anatolia high schools and found that teachers perceived the school administrators' effectiveness at moderate level. Sağım (2008) also found in his study focusing on the school administrators' effective administrative behaviours in Anatolia High Schools that the school administrators usually show effective administrative behaviours. Kuzubaşıoğlu and Çelebi (2009) found the effectiveness level of the school administration in normal high schools as 3.93 (in a likert type with 5 items). In a study done by Scott, Parsley and Fantz (2014) in 75 schools in Idoha with 1745 teachers, it was found that the effective school leadership dimension score was at a high level with 4.28. Lempesis (2009) carried out a study in which he tried to measure the effectiveness of the school administrators in successful and unsuccessful schools and made some comparisons. It was found that the effectiveness scores of the school administrators in successful schools was 3.76 and those in unsuccessful schools was 4.00. According to these results, the school administrators display effective behaviours in high levels.

Çubukçu and Girmen (2006) performed a study on teachers' opinions about the school administrators behaviours which are considered as one of the most important criteria of the effective high schools and found that teachers perceived their school administrators as effective in such behaviours as supporting the school achievement, communication with parents and environment of the school although they consider the school administrators as insufficient in such behaviours as leading to teachers in educational issues and supporting them. The effective school leadership behaviours were found as sufficient in some sub-dimensions and as at moderate level in some sub-dimensions.

Gökçe and Kahraman (2010) carried out a study on the components of the effective school, evaluated the school administrators in the leadership dimension and found that the school administrators were efficient in general $(\bar{x}=4,54)$. Yalçın (2010) found in this study on school improvement that the participants perceived the school administrators' school leadership behaviours were high level. The teachers mentioned positive statements in management of human and physical resources and environment-society relations as to their school administrators.

Dağlı (2000) performed a study on the secondary school administrators' effective administrative behaviours and found that teachers perceived their school administrators' behaviours as at moderate level with regard to effective school leadership. Gündüz and Bayer (2012) also found that the effective leadership behaviours of the school administrators according to the opinions of the teachers were 2.84, which indicates a moderate level. In their studies examining the effective leadership levels of the primary school administrators, Aybek, Titiz and Gümüşay (2014) found that school administrators always show effective leadership behaviours. Tahaoğlu and Gedikoğlu (2009) also examined the leadership roles of the secondary school administrators and found that visionary leadership roles are the most frequent ones showed by school administrators.

There haven't been many studies on effective school leadership, but there are studies in the scope of administrative sub-dimensions of the studies focusing on effective school. This situation limits the study results to compare with the previous ones. However, as far as it can be done as partial comparisons, it can be stated that the results of this study correspond to the previous studies done on the similar themes (Çubukçu and Girmen, 2006; Dağll, 2000; Güçlü and Tunçel, 2010; Lempesis, 2009; Kuzubaşığlu and Çelebi, 2009; Sağım, 2008; Scott, Parsley and Fantz, 2014). 
Ata, E., \& Güçlü, N. (2018). The relationship between selfself-efficacy beliefs of school administrators and effective school leadership. Journal of Human Sciences, 15(2), 1137-1154. doi:10.14687/jhs.v15i2.5197

\section{The Relationship between the Self-efficacy Beliefs of the School Administrators and the Effective School Leadership}

Before testing the relationship between the self-efficacy beliefs of the school administrators and the effective school leadership, Kolmogorov-Simirnov Test was done in order to check the normality assumption and it was found that this condition couldn't be fulfilled. For this reason, Spearman Brown rank differences correlation coefficient which is a non-parametric test was used to evaluate the relation between the variables.

When the Anatolia High School and vocational high school administrators were evaluated together and the number of the school administrators are $60(n=60)$, teachers evaluating are 922 $(n=922)$, the Spearman Brown rank differences correlation coefficient was found as $r=0.106$ for the general scores of the school administrators' self-efficacy and effective school leadership. For the significance of the coefficient, $\mathrm{p}$ value was found as $\mathrm{P}=0.001$. Since this value is smaller than the significance value of 0.01 , it can be said that the correlation coefficient is significant. There is a significant relation in the same direction between the self-efficacy of the school administrators and effective school leadership scales as the correlation coefficient is bigger than zero when the Anatolia High School and vocational high school administrators are evaluated together (The significance level was based on as 0.01).

When the Anatolia High School and vocational high school Administrators were evaluated separately, the number of Anatolia High School Administrators and the school administrators are $30(\mathrm{n}=30)$, teachers being evaluated are $447(\mathrm{n}=447)$, the Spearman Brown rank differences correlation coefficient was found as $r=0.90$ for the general scores of the school administrators' selfefficacy and effective school leadership. For the significance of the coefficient, $\mathrm{p}$ value was found as $\mathrm{P}=0.058$. Since this value is bigger than the significance value 0.05 , the correlation coefficient is of no significance and cannot be evaluated. Therefore, it can be said that there is no significant relation between the self-efficacy beliefs and effective school leadership of the Anatolia High School Administrators (The significance level was based on as 0.05).

The vocational high school administrators and the number of the school administrators are $30(n=30)$, teachers being evaluated are $475(n=475)$, the Spearman Brown rank differences correlation coefficient was found as $\mathrm{r}=0.094$ for the general scores of the school administrators' self-efficacy and effective school leadership. For the significance of the coefficient, $p$ value was found as $P=0.041$. Since this value is smaller than the significance value of 0.05 , it can be said that the correlation coefficient is significant and can be evaluated. Since R correlation coefficient is bigger than zero, there is a significant relation in the same direction between the self-efficacy of the school administrators and effective school leadership scales for the Vocational High School Administrators. (The significance level was based on as 0.05).

The studies about the relationship between the self-efficacy level of the school administrators and effective school leadership haven't been able to access to in the literature. However, selfefficacy is studied with other variables such as success, showing effort, developing the innovations and effectiveness. In line with tis, Tintavee (2010) carried out a study on the behaviours of the school administrators and skills and found a linear causal link between the effective school leadership and effective leadership behaviours (0.89). Woods (2004) also found that there is a significant relation between self-efficacy and transformational leadership behaviours of the administrators of the students' affairs. Transformational leaders increase the effectiveness of the leadership thanks to inspiring motivation and intellectual stimulation for the individuals and groups. Along with Tintavee (2010) and Woods (2004), there are other studies which show similarities with this study. In one of these, Hebert (2010) studied on the effectiveness and found that there is a high level relation between the transformational leadership and effectiveness (Pearson's $r=90<.01$ ). 
Ata, E., \& Güçlü, N. (2018). The relationship between selfself-efficacy beliefs of school administrators and effective school leadership. Journal of Human Sciences, 15(2), 1137-1154. doi:10.14687/ihs.v15i2.5197

\section{The Self-efficacy Beliefs of the School Administrators Predicting the Effective School Leadership}

Simple linear regression analysis was performed so as to find out whether the self-efficacy beliefs of the school administrators working in Anatolia High Schools and vocational high schools predict the effective school leadership levels. The regression analysis results which were formed by defining the total score obtained from the self-efficacy scale applied to school administrators working in Anatolia High Schools and vocational high schools as independent variable (predictor) and the total score obtained from the effective school leadership applied to teachers as dependent variable (predicted) were shown in Table 4.

As shown in Table 4, the predicted model is significant since $\mathrm{p}$ value $(\mathrm{P}=0,00)$ of the test is smaller than the significance value of 0.01 . Therefore, it can be argued that the self-efficacy beliefs of the school administrators predict the effective school leadership levels regardless of school type.

Table 4. The Regression Analysis for the School Administrators

\begin{tabular}{lccccc}
\hline Independent Variable & $\widehat{\boldsymbol{\beta}}$ & $\mathbf{R}$ & $\mathbf{R}^{\mathbf{2}}$ & $\mathbf{F}$ & $\mathbf{P}$ \\
\hline Self-efficacy & 0,292 & 0,346 & 0,12 & 14,17 & 0,000 \\
\hline
\end{tabular}

Dependent V ariable: Effective School Leadership; n:922

The predicted regression coefficient for the self-efficacy belief levels of the school administrators was found as 0.292 . This coefficient is significant and can be evaluated since $\mathrm{P}$ value $(\mathrm{P}=0.000)$ obtained through t-test done to test significance is smaller than the significance value of 0.01. Therefore, since this coefficient is positive, it can be said that there is a linear relation in the same direction between the self-efficacy beliefs of the school administrators and effective school leadership.

\section{Comparison of the Self-Efficacy Belief Levels of the School Administrators in terms of Their Employment Styles}

Table 5. Mann-Whitney U Test Results of the Differences Between Employment Styles In Terms of Self-Efficacy Belief Levels of the School Administrators

\begin{tabular}{|c|c|c|c|c|c|c|c|c|}
\hline \multirow[b]{2}{*}{ Variable } & \multirow[b]{2}{*}{$\begin{array}{c}\text { Employment } \\
\text { Style }\end{array}$} & \multicolumn{7}{|c|}{ Mann-Whitney U } \\
\hline & & $\mathbf{N}$ & $\bar{x}$ & Median & $\mathbf{S}$ & $\begin{array}{l}\text { Mean } \\
\text { Rank }\end{array}$ & $\mathrm{Z}$ & $\mathrm{p}$ \\
\hline \multirow{3}{*}{$\begin{array}{c}\text { Self-Efficacy } \\
\text { of School } \\
\text { Administrator }\end{array}$} & Appointment & 37 & 6,12 & 6,2 & 0,58 & 27,55 & \multirow{2}{*}{1,658} & \multirow{2}{*}{0,097} \\
\hline & Exam & 23 & 6,36 & 6,6 & 0,54 & 35,24 & & \\
\hline & Total & 60 & 6,21 & 6,3 & 0,57 & & & \\
\hline
\end{tabular}

$*_{\mathrm{p}}>0.05$

As shown in Table 5 , the $61.7 \%$ of the school administrators were employed through appointment, while $38.3 \%$ of them were employed by means of an exam. The mean of the selfefficacy scores of the school administrators employed via appointment was found as 6.12, whereas those employed through exam was found as 6.36. As a result of the result of the Mann-Whitney $U$ test, $\mathrm{p}$ value was calculated as 0.097 . Since this value is bigger than $\mathrm{p}>0.05$, it can be stated that there is no significant difference between the school administrators employed through exam or the ones employed through appointment in terms of the self-efficacy belief levels (Table 5). 
Ata, E., \& Güçlü, N. (2018). The relationship between selfself-efficacy beliefs of school administrators and effective school leadership. Journal of Human Sciences, 15(2), 1137-1154. doi:10.14687/jhs.v15i2.5197

\section{Comparison of the Effective School Leadership Levels of the School Administrators In Terms of Their Employment Styles}

Table 6. Independent T-Test Results of the Differences between Employment Styles In terms of Effective School Leadership Levels of the School Administrators

\begin{tabular}{ccccccccc}
\hline & & \multicolumn{7}{c}{ Independent t-test } \\
\hline Variable & Employment & $\mathbf{N}$ & $\bar{x}$ & $\mathbf{S}$ & $\mathbf{s d}$ & $\mathbf{t}$ & $\mathbf{p}$ \\
& Style & & & & & \\
Appointment & 37 & 4,88 & 5,0 & 0,78 & & \\
Effective School & Exam & 23 & 5,27 & 5,2 & 0,64 & $-2,042$ & $\mathbf{0 , 0 4 6 *}$ \\
Leadership & Total & 60 & 5,03 & 5,1 & 0,75 & & \\
& & & & & & &
\end{tabular}

$*_{\mathrm{p}}<0.05$

As shown in Table 6, the mean scores of effective school leadership of the school administrators employed through appointment was 4.88, while those employed through exam was 5.27. T-test result was found as $\mathrm{p}=0,046^{*}$. Since this value is smaller than $\mathrm{p}<0.05$, it can be argued that there is a significant difference between the effective school leadership levels of the school administrators employed through appointment and those employed through exam. In order to find out the effect size of the employment style of the school administrators on the effective school leadership, eta-squared value was calculated as $\eta 2=0,062$. From this result, it can be stated that approximately $6 \%$ of the effective school leadership levels is affected by the employment style of the school administrators. In other words, the employment situations of the school administrators have an impact on the approximately $6 \%$ of the scores of the effective school leadership.

In this study, the similar studies were included for the discussion since the studies on whether the effective school leadership levels of the school administrators change according to their employment styles haven't been able to access. In one of those studies, Özkahya (2003) carried out a study concentrating on the teachers' perceptions related to the effectiveness levels of the school administrators employed through exam or without exam by the Ministry of National Education and found that the school administrators employed through exam are more effective in school administration than those without exams. Özmen and Yörük (2004) also studied on the effectiveness of the school administrators employed through exams and found a moderate level of effectiveness of the school administrators. Another study on school administration employment through exam and organizational commitment was conducted by Balay and Çevik (2014) and it was found that the organizational commitments of the school administrators employed through exam was at moderate level.

\section{Results}

1. The self-efficacy beliefs of the school administrators working in Anatolia High Schools and vocational high schools were found as at high level. This result can be considered as a positive situation.

2. According to the opinions of the teachers, the effective school leadership levels of the school administrators were found as at high level in general.

3. The self-efficacy beliefs of the school administrators didn't show any significant differences in terms of school types. However, the self-efficacy levels of the Anatolia High Schools were observed as high.

4. According to the opinions of the teachers, the effective school leadership levels of the school administrators didn't show any significant differences in terms of school types.

5. A meaningful relation in the same direction was found between the self-efficacy beliefs of the school administrators and effective school leadership levels according to teachers' opinions. 
Ata, E., \& Güçlü, N. (2018). The relationship between selfself-efficacy beliefs of school administrators and effective school leadership. Journal of Human Sciences, 15(2), 1137-1154. doi:10.14687/jhs.v15i2.5197

6. The self-efficacy levels of the school administrators predict the effective school leadership levels. In general, a meaningful relation in the same direction was found between the selfefficacy beliefs of the school administrators and effective school leadership levels according to teachers' opinions by means of regression analysis. When the school types are evaluated separately, it can be said that the self-efficacy levels of the school administrators predict the effective school leadership levels

7. Even though the employment styles of the school administrators either through exam or through appointment means some meaningful differences in self-efficacy beliefs, there is no significant difference between the two groups in this study.

8. The effective school leadership levels of the school administrators generally show meaningful differences in terms of the employment style.

\section{Suggestions}

Some useful suggestions can be made for the appliers and researchers in the light of the results obtained in the study:

1. The fact that the self-efficacy levels of the school administrators is a predictor of the effective school leadership increase the importance of the self-efficacy in the school administration. For this reason, there must be some studies for both active and prospective school administrators, such as designing and enriching the content of the curriculum of the programmes planned to train the school administrators.

2. The fact that the school administrators' effective school leadership levels are high according to the opinions of teachers necessitate that some trainings must be done to increase the effective school leadership levels of the school administrators.

3. The self-efficacy levels of the school administrators show some differences in vocational high schools. Therefore, some applications such as taking role models, forming experiences, encouraging socially may add some positive contributions to self-efficacy levels of the school administrators.

4. The fact that there is a meaningful relation between the self-efficacy beliefs of the school administrators and effective school leadership levels show the importance of the selfefficacy beliefs and effective school leadership levels of the school administrators. For this reason, some different studies with different methods such as questionnaire or interviews, etc. and statistical tests can be done on the self-efficacy and effective school leadership of the school administrators.

5. The fact that the school administrators have been employed according to some exams explaining the high levels of self-efficacy. Having been employed as a result of some efforts and study session is important for a successful and effective school administration. For this reason, the exams which are carried out to employ school administrators must be given priority and importance and the scope of these kind of exams must be expanded.

6. The fact that the school administrators have high levels of effective leadership shows the importance of being employed as a result of some kinds of exams done to select school administrators. On the other hand, the scope and content of these exams must be redesigned and updated in order to make them more valid and reliable.

7. Studies can be carried not only for the self-efficacy of the school administrators related to school administration, but for self-efficacy in general as well.

8. This study is a cross-sectional one. Longitude and repeated studies which are based on longer periods with regard to self-efficacy and school leadership can be done.

9. Interview and observation techniques can be performed in order to increase the validity and reliability of the similar studies.

10. Similar studies can be repeated with different samples based on such variables as age, branch, student numbers. 
Ata, E., \& Güçlü, N. (2018). The relationship between selfself-efficacy beliefs of school administrators and effective school leadership. Journal of Human Sciences, 15(2), 1137-1154. doi:10.14687/jhs.v15i2.5197

Similar studies can be carried out on deputy school administrators and candidate school administrators in order to measure their self-efficacies.

\section{References}

Açıkalın, A. (1998). Toplumsal ve kurumsal teknik yönleriyle okul yöneticiliği. Ankara: Pegem.

Alpar, R. (2010). Uygulamah istatistik ve geçerlik güvenirlik. Ankara: Detay.

Abussam, J. (2010). Devoloping efficacy in school leaders (Unpublic doctoral dissertation). California State University, Fullerton. Can be accessed the database of ProQuest Dissertations and Theses Global (UMI No:3405539).

Altunışık, R., Coşkun, R., Bayraktaroğlu, S. V. \& Yıldıım, E. (2007). Araştırma yöntemleri. Sakarya: Sakarya

Armor, D., Conroy-O., P., Cox, M., King, N., McDonnell, L., Pascal, A. (1976) Analysis of the school preferred reading programs in selected LosAngeles minority schools. (Report No. R-2007-LAUSD). Santa Monica, CA.

Autry, S. C. W. (2010). The relationship between the self-efficacy of the principal and the collective efficacy of the faculty (Unpublished doctoral dissertation). Virginia University. Can be accessed the database of ProQuest Dissertations and Theses Global. (UMI No: 3442302).

Aybek, B. Titiz, H. ve Gümüşay, T. (2014) İlkokul müdürlerinin etkili liderlik düzeylerine ilişkin öğretmen görüşlerinin incelenmesi. Ë̈itim ve Ögretim Araştrrmalar Dergisi 3 (4). 342-355

Ayık, A., Savaş, M. \& Yücel, E. (2015). İlkokularda görev yapan okul müdürlerinin genel öz yeterlik ile örgütsel bağlllılık algılan arasındaki ilişkinin incelenmesi. Uşak Üniversitesi Sosyal Bilimler Dergisi, 8(2). 193-2178

Balay, R. \& Çevik, M. N. (2014, Mayıs). Ë̆itim kurumu yöneticilerinin atanma şekillerine göre örgütsel bağhllklar. 9. Ulusal Eğitim Yönetimi Kongresinde Sunulmuş Bildiri. Siirt Üniversitesi, Siirt.

Balc1, A. (2001). Etkili okul ve okul gelistirme. Ankara: Pegem.

Balc1, A. (2004). Sosyal bilimlerde arastrma. Yöntem, teknik ve ilkeler. Ankara: Pegem.

Bandura, A. (1977). Self-efficacy: Toward a unifying theory of behavioral change. Psychological Review, 84(2), $191-215$.

Bandura, A. (2002). Self-efficacy in changing societies. United Kingdom: Cambridge University Pres

Bandura, A. (2003). Cultivate self-efficacy for personal and organizational effectiveness. Edwin A. Locke (Ed.), Handbook of Principles of Organization Behavior içinde (s.121-140) Oxford: Blackwell.

Berman, P., McLaughlin, M., Bass, G., Pauly, E. \& Zellman, G. (1977). Federal programs supporting educational change. VII Factors affecting implementation and continuation (Report No. R-1589/ 7-HEW) Santa Monica, CA: Rand Corporation. (ERIC Document Reproduction Service No. 140 432). Retrieved from January, 20, 2015 from http://files.eric.ed.gov/fulltext/ED140432. Pdf.

Bulanch, C., Boothe, D. \& Picket, W. (2006). Analyzing the leadership behaviour of school principals. Retrieved on 21 May 2013 http:// www.cnx.org/org/content/m13813/latest

Büyüköztürk, Ş. (2009). Sosyal bilimler için veri analizi el kitabı. Ankara: PegemA.

Büyüköztürk, Ş., Çakmak, E. K., Akgün, Ö. E., Karadeniz, Ş. \& Demirel, F. (2011). Bilimsel arasstrma yöntemleri. Ankara: PegemA.

Cemaloğlu, N. (2007). Okul yöneticilerinin liderlik stillerinin farklı değişkenler açısından incelenmesi. Türk Eg̈itim Bilimleri Dergisi, 5(1),73-112.

Chen, G., Gully, S. M. \& Eden, D. (2004). General self-efficacy and self-esteem: tonxord theoritical and emprical distinction between correlated self-evaluations. Journal of Organizational Behavior, 25(3), 375395.

Çubukçu, Z. \& Girmen, P. (2006). Ortaöğretim kurumlarının etkili okul özelliklerine sahip olma düzeyleri. Retrieved on April 3, 2012 from http://journals.manas.edu.kg/mjsr/oldarchives/ Vol08Issue162006/534-1422-1-PB.pdf.

Dağlı, A. (2000). İlköğretim öğretmenlerinin algllarına göre ilköğretim müdürlerinin etkili müdürlük davranısları. Kuram ve Uygulamada Eğitim Yönetimi, 6(3),431-442.

Domsch, G. D. (2009). A study investigating relationships between elemantary principals' and teachers' self-efficacy and student achievement (Unpublihed doctoral dissertation). Sait Luis University. Can be accessed the database of ProQuest Dissertations and Theses Global (UMI No:3383305).

Federici, R. A.\& Skaalvik, E. M. (2012b). Principal self-efficacy and work engagement: Assesing a Norwegian principal self-efficacy scale. Soc. Psychol. Educ,14(4), 576-600.

Gist, M. E. \& Mitchell, T. R. (1992). Self- eficacy: A theoretical analysis of its determinants and malleability. The Academy of Management Rewiew, 17 (2), 183-211. 
Ata, E., \& Güçlü, N. (2018). The relationship between selfself-efficacy beliefs of school administrators and effective school leadership. Journal of Human Sciences, 15(2), 1137-1154. doi:10.14687/jhs.v15i2.5197

Gökçe, F. \& Kahraman, P., B. (2010). Etkili okulun bileşenleri: Bursa ili örneği. Uludağ Ü. Eğ̈tim Fakültesi Dergisi, 13(1), 173-206

Güçlü, N. (1997). Eğitim yöneticisi olarak okul yöneticisi. Milli Eğitim Dergisi, 134,50-54

Güçlü, N. \& Tunçel, M. (2010). Genel liseler ve Anadolu liselerinin etkili okul olma özelliklerinin karşzlasttrlmast (Ankara İli Örneği) V. Ulusal Eğitim Yönetimi Kongresi. Bildiriler Kitabı. Ankara: Nobel.

Gümüsseli, A. İ. (1996). İstanbul ilindeki ilkögretim okulu müdürlerinin ögretim liderlĭgi davranışlar (Yayımlanmamıs arastirma). Retrieved from February 3, 2010 from http://www. agumuseli.com/ dokumanlar/arastirma/liderlik 01.pdf.

Gündüz, Y. \& Balyer, A. (2012). Okul müdürlerinin etkili liderlik davranşlarmn incelenmesi. Kuramsal Eğitim bilim Dergisi, 5(2), 237-253.

Harris, A. (2002). Effective leadership in schools facing challenging contex. Scohool Leadership And Management, 22(1), 15-26.

Harris, A., Day, C. \& Hadfield, M. (2003). Teachers' perspectives on effective school leadeship. Teachers and Teacbing Theory and Practice, 9(1), 66-77.

Hebert, E. B. (2010). The relationship between emotinal intelligence, transformational leadership and effectivenes in school principals (Unpublished doctoral dissertation). Georgia State University. Can be accessed the database of ProQuest Dissertations and Theses Global (UMI No:3447903).

Herriot, J. A. (2012). Characteristics of effective principals: Evidence from the 1999-2000 schools and staffing survey (Unpublished thesis of masters. Geogertown University. Can be accessed the database of ProQuest Dissertations and Theses Global (UMI No:1508567).

Hoy, W. K. \& Miskel, C. (2010). Eğitim yönetimi (S. Turan, Çeviri Edi.). Ankara: Nobel.

İnand, Y. \& Özkan, M. (2006). Resmi ilköğretim ve liselerde görev yapan yönetici ve öğretmenlerin görüşlerine göre müdürler ne derece öğretim liderliği davranışlanı göstermektedirler. Mersin Üniversitesi Ë̆itim Fakïltesi Dergisi, 2(2), 123-149.

Işsk, İ. (2001). Öz yeterlik inanc: yönetici rolleri agısından inceleme (Yayımlanmamış Doktora tezi) Marmara Üniversitesi Sosyal Bilimler Enstitüsü. İstanbul.

Karaman, F. (2008). Ortä̈ğretim okullarnnda görev yapan okul müdürlerinin göstermiş olduğu liderlik ve etkili yöneticilik davramş̧lar. Yüksek Lisans Tezi, Beykent Üniversitesi Sosyal Bilimler Enstitüsü, İstanbul.

Krüger, M., Witziers, B. \& Sleegers, P. (2007). The impact of school leadership on school level factors: Validation of casual model. School Effectiveness and School Improvement, 18(1),1-20.

Kurt, T. (2012). Öğretmenlerin öz yeterlik ve kolektif yeterlik algiları. Türk Ë̆itim Bilimleri Dergisi, 10(2), 195227

Kuzubaşığlu, D. \& Çelebi, N. (2009, Mayıs). Genel liselerdeki ögretmenlerin deģ̆̈sim yönetimi faktörlerine ilişkin algilarmm etkili okul açssından değerlendirilmesi.1.Eğitim Araşturmalant Kongresinde sunulmuş bildiri, 18 Mart Üniversitesi, Çanakkale.

Leithwood, K. \& Jantzi, D. (2008). Linking leadership to student learning: The contibutions of leader efficacy. Educational Administration Qurterly ,44 (4), 496-528.

Lovell, C. W. (2009). An investigation of school principals' sense of efficacy and indicators of school effectiveness (Unpublished doctoral dissertation). University of Missouri. Columbia. Can be accessed the database of ProQuest Dissertations and Theses Global (UMI No:3396135).

Lunenburg, L. \& Ornstein, A. C (2013). Ë̈tim yönetimi (G. Arastamam, Çeviri Edi.). Ankara: Nobel.

Lyons, C. A. \& Murphy, J. M. (1994). Principal self-efficacy and the use power. Annual Meeting Of American Educational Research Assocation. New Orleans, La. Retrieved on April, 4-8, 2011 from http://files.eric.ed.gov/fulltext/ED373421.

Markman, G. D. , Baran, R. A. \& Balkin, D. B. (2005). Are perseverance and self-efficacy castless? Assessing entrepreneurs' regretful things. Journal of Organizational Behaviour,26,1-19.

McCollum, D. L. \& Kajs, L. T. (2007). School administrator efficacy. Ancances in Educational Administration, 10,131-148.

McCollum, D. L. \& Kajs, L. T. (2009). Examining the relationship between school administrators' effficacy and goal orientations. Educational Research Quarterly, 32(3), 29-46

McCollum, D. L. Kajs, L. T. \& Minter, N. (2006). School adminisrators efficacy: A model and measure. In Academy of Educational Leadeship, 10(1), 29-33.

McCormick, M. J. (2001). Self-efficacy and leadership effectivenecess: applying social cognitive theory to leadership. The Journal of Leadership Studies, 8(1), 22-33. 
Ata, E., \& Güçlü, N. (2018). The relationship between selfself-efficacy beliefs of school administrators and effective school leadership. Journal of Human Sciences, 15(2), 1137-1154. doi:10.14687/jhs.v15i2.5197

McCullers, J. F. \& Bozeman, W. (2010). Principal self-efficacy: The effect of no child left behind and florida school grandes. NASP Bulletin, 94(1), 53-74,15.

McCullers, J. F. (2009). Self-efficacy beliefs of florida school principals regarding federal and state accountability measures (Unpublished doctoral dissertation. Florida Central University. Can be accessed the database of ProQuest Dissertations and Theses Global (UMI No: 3401809).

Moak, J. (2010). The self-perception of leadership efficacy of elemantary principals and the effects on student achievement (Unpublished doctoral dissertation). University of MiSouri. Columbia. Can be accessed the database of ProQuest Dissertations and Theses Global (UMI No: 3488809).

Moran, M. T. \& Gareis, C. R. (2005, November). Cultivating principals' sense of efficacy supports that matters. Presented At The Annual Meeting of The University Council for Educational Administration. Nashville. Retrieved on 12 December Ucea.org/storage/conventation.

Nikolas, J. M. (2013). The relationship between principals' and teacher' self-efficacy beliefs (Unpublished doctoral dissertation). South Dakota University. Can be accessed the database of ProQuest Dissertations and Theses Global (UMI No: 3607726).

Nye, G. D. (2008). Principals leadership belief: Are personel and enviromental influences related to selfefficacy (Unpublished doctoral dissertation). North Texas University, Teksas. Can be accessed the database of ProQuest Dissertations and Theses Global. (UMI No: 3376045).

O'Neil, G. M. (2013). The influence of self-efficacy on principals' capacity to lead in low socioeconomic status schools (Unpublished doctoral dissertation). University of Calgary, Canada. Can be accessed the database of ProQuest Dissertations and Theses Global (NS22986).

Özkahya, S. (2003). Milla Eğitim Bakanluğ tarafindan, sinavla ve sinavsı atanan okul yöneticilerinin, etkililike dïreylerine ilişkin ögrretmen algzlar. Yüksek Lisans Tezi, Trakya Üniversitesi Üniversitesi, Sosyal Bilimler Enstitüsü, Edirne.

Özmen, F. \& Yörük, S. (2004, Temmuz). Sinavla atanan ilkögretim okulu yöneticilerinin ögretmenlerin mesleki gelisimindeki etkililike dïregleri-Malatya ili örneği. XIII. Eğitim Araşurmalan Kongresinde sunulmuş bildiri, İnönü Üniversitesi, Malatya.

Sağım, R. (2008). Öğretmen algzlarna göre Anadolu lisesi müdïrlerinin etkili müdürlïle davramışlar. Yüksek Lisans Tezi, Yıldız Teknik Üniversitesi Sosyal Bilimler Enstitüsü, İstanbul.

Şahin, F. (2009). Yönetsel güclülïk. Doktora Tezi, Niğde Üniversitesi, Sosyal Bilimler Enstitüsü, Niğde.

Scott, C., Parsley, D. \& Fantz, T. (2014). Connections between teacher perceptions of school effectiveness and student outcomes in Idaho's low-achieving schools. Regional Educational Laboratory Northwest administered by Education Northwest. Retrieved on January 15, 2015 from http://ies.ed.gov/ ncee/edlabs.

Simith, W., Guarino, A., Storm, P. \& Adams, O. (2006). Effective teaching and learning enviroments and principal self-efficacy. Journal of Research for Educational Leaders,3(2),4-23.15.

Snijder, T. A. B. \& Bosker, R. J. (2010). Multilevel analysis. Sage Puplications. Retrieved on December 7, 2011 from statgamma ug.nl/MLB-S.

Tahaoğlu, F. \& Gedikoglu, T. (2009). İlköğretim okulu müdürlerinin liderlik rolleri. Kuram ve Uygulamada Eğitim Yönetimi, 15(58), 274-298

Tahir, L. M., Said, H. \& Rahman, H. A. (2011). Characterictics of effective school principals. Retrieved on March 5, 2011 from http://www.ikp.um.edu.my/images/ipk/doc.

Tavşancil, E. (2006). Tutumlarn ölçülmesi ve SPSS ile veri analizi. Ankara: Nobel.

Tintavee, P. (2010). Development of effective private billingual school's principal leadership. Structral Casual Model: Behaviors and Skills. Review of Business Reserarch, 10(1), 268-274.

Uluğ, F. (2010). Eğitimde sistem reformu bağlaminda yönetici yetiștirme ve istibdam. V. Ulusal Eğitim yönetimi Kongresi Bildiriler Kitabı. Ankara: Nobel.

Waters, T., Marzano, R. J. \& McNulty, B. (2003). Balanced leadership. A working paper, 1-9. Retrieved on April 10, 2011 from http://www.mcrel.org/balancedleadership.pdf.

Wood, R. \& Bandura, A. (1989). Social cognitive theory of organizational management. The Academy of Management Review, 14(3), 361-384.

Woods, S. R. (2004). The effects of self-efficacy, transformational leadership and trust on leadership effectiveness of senior student affairs officers (Unpublished doctoral dissertation). Regent University. Can be accessed the database of ProQuest Dissertations and Theses Global (UMI No: 3158538).

Yıldırım, A. \& Şimşek, H. (2013). Sosyal bilimlerde nitel araștırma yöntemleri. Ankara: Seçkin. 